\title{
The Predictive Factors for Prolonged Seizures and Status Epilepticus: A Single Center Study
}

\section{Uzamış Nöbet ve Status Epileptikus için Risk Faktörleri: Tek Merkez Deneyimi}

\author{
Müge Ayanoğlu ${ }^{1 \oplus} \oplus$ Ebru Atike Ongun ${ }^{2} \odot$ \\ ${ }^{1}$ Sivas Numune State Hospital, Department of Pediatric Neurology, Sivas, Turkey \\ ${ }^{2}$ Cumhuriyet University, Pediatric Intensive Care Unit, Sivas, Turkey
}

Received: 30.06.2020 / Accepted: 17.02.2021 / Published Online: 31.03.2021

Cite as: Ayanoğlu M, Ongun EA. The predictive factors for prolonged seizures and status epilepticus: a single center study. Med J Bakirkoy 2021;17(1):53-63.

ABSTRACT

Objective: To analyze the clinical features of prolonged seizures and status epilepticus and perform risk analysis on super refractory status epilepticus (SRSE) in pediatric intensive care unit (PICU) admissions.

Method: Demographic features, underlying etiologies, treatment modalities, electroencephalographic and neuroimaging outcomes of intensive care unit admissions between 2015 and 2019 were analyzed.

Results: Seventy-one children were enrolled. The most common etiologic factors for prolonged seizure were fever in $45.1 \%$, (central nervous system infection: $16.9 \%$, infection other than central nervous system: $28.2 \%$ ), withdrawal of the antiepileptic medication in $40.9 \%$, intoxications in $12.7 \%$ of the children and intracranial hemorrhage due to arteriovenous malformation in one (1.4\%) patient. At admission hypoglycemia was detected in $23.9 \%$, hypocalcemia in $18.3 \%$, hyponatremia in $15.5 \%$, acidosis in $35.2 \%$, and increased lactate levels in $25.4 \%$ of the patients. The patients were grouped based on fever at admission and new-onset seizure. Approximately $45.1 \%$ of the population had fever at admission and consisted of younger children compared to their counterparts $(p=0.023)$. Children with pre-existing epilepsy had frequent history of sibling death, while patients presented with newonset seizure had more often significant lactate elevations, acidosis, and required mechanical ventilation at admission $(p=0.002, p=0.008, p=0.017)$. Twelve (16.9\%) patients developed SRSE. Low serum sodium and calcium levels increased the risk of developing SRSE (OR: 10.800, 95\%Cl: 2.518-46.318; OR: 4.554, 95\%Cl: 1.159-17.892). However PRISM-3 score has been identified as the single independent risk factor for SRSE (OR: 1.174, 95\% Cl: 1.0391.327). Three (4.2\%) children died of secondary complications during their stay in intensive care unit. Tracheostomy cannulation was performed in two (16.7\%) SRSE patients due to neurological incapability to maintain a patent airway.

Conclusion: PRISM-3 score is the independent risk factor of SRSE. Electrolyte abnormalities (hyponatremia and hypocalcemia) are associated with developing SRSE.

Keywords: Seizure, Status epilepticus, Super refractory status epilepticus, Hyponatremia

öz

Amaç: Çocuk yoğun bakım ünitelerindeki uzamış nöbet ve status epileptikusun klinik özelliklerinin analiz edilmesi ve süper direçli status epileptikusun (SRSE) risk analizinin yapılması

Gereç-Yöntem: 2015-2019 yılları arasında çocuk yoğun bakım ünitesine başvuran uzamış nöbet ve status epileptikus olgularının demografik özellikleri, altta yatan etiyolojileri, tedavi modaliteleri, elektroensefalografik ve nörogörüntüleme sonuçları incelendi.

Bulgular: Yetmiş bir olgu çalıșmaya dahil edildi. En sık etyolojik nedenlerin \%45.1 olguda ateș (santral sinir sistemi enfeksiyonları: \%16.9, santral sinir sistemi dışında enfeksiyonlar: \%28.2), \%40.9 olguda antiepileptik tedavinin kesilmesi, \%12.7 olguda intoksikasyonlar ve bir olguda (\%1.4) arteriovenöz malformasyona bağlı intrakraniyal kanama olduğu gözlendi. Bașvuru anında \%23.9 olguda hipoglisemi, \%18.3 olguda hipokalsemi, \%15.5 olguda hiponatremi, \%35.2 olguda asidozis ve \%25.4 olguda artmış laktat seviyeleri saptandı. Olgular, nöbet esnasında ateş varlığı ile önceden geçirilmiş nöbet öyküsü olup olmamasına göre gruplara ayrıldı. Başvuru anında ateș, \% 45.1 olguda mevcut iken, bu olguların afebril nöbet geçirenlere göre daha küçük yaşta hastalardan oluştuğu görüldü ( $p=0.023$ ). Önceden geçirilmiş nöbet öyküsüne sahip olgularda sık kardeş ölüm öyküsünün olduğu, ilk kez nöbet ile başvuran olgularda ise yatış anında laktat yüksekliği ve asidozun belirgin, mekanik ventilasyon gereksinimin ise sık olduğu gözlendi ( $p=0.002, p=0.008$, $p=0.017)$. Oniki (\%16.9) hastada SRSE geliști. Bu olgularda düşük serum sodyum ve kalsiyum seviyelerinin SRSE gelişim riskini artırdığı anlaşıldı (OR: 10.800, 95\% Cl: 2.518-46.318; OR: 4.554, 95\% Cl: 1.159-17.892). Çoklu regresyon analizinde, PRISM-3 skorunun SRSE için tek bağımsız risk faktörü olduğu saptandı (OR: 1.174, 95\% Cl: 1.039-1.327). Üç (\%4.2) olgu, çocuk yoğun bakım yatısıı esnasında ikincil komplikasyonlar sonucu kaybedildi. SRSE gelișen iki olguda (\%16.7) nörolojik olarak hava yolu açıkı̆̆ını koruyamama nedeniyle trakeostomi kanülizasyonu uygulandı.

Sonuç: PRISM-3 skoru SRSE için bağımsız risk faktörüdür. Elektrolit dengesizliği (hiponatremi, hipokalsemi) SRSE gelişimiyle ilişkilidir.

Anahtar kelimeler: Nöbet, Status epileptikus, süper dirençli status epileptikus, hiponatremi

The English in this document has been checked by at least two professional editors, both native speakers of English. For a certificate, please see: http://www.textcheck.com/certificate/ux3rus

Corresponding Author:

mugeayanoglu_05@hotmail.com

M. Ayanoğlu 0000-0002-0556-1435 E.A. Ongun 0000-0002-1248-8635 


\section{INTRODUCTION}

Seizure is the sudden onset of abnormal electrical discharge owing to excessive or synchronous neuronal activity in the brain ${ }^{(1)}$. In patients with prolonged symptoms, seizures can become a much more complicated, life-threatening condition known as status epilepticus (SE) ${ }^{(1,2)}$. The International League Against Epilepsy (ILAE) has proposed a consensus definition of prolonged seizures and SE. The first dimension of this definition is the time point $\left(t_{1}\right)$ at which the seizure should be considered a prolonged seizure, and the second dimension $\left(t_{2}\right)$ is the duration of ongoing seizure activity that conveys the risk of long-term consequences. In tonic-clonic seizures, the ILAE task force's novel description of prolonged seizure is epileptic activity of $>5 \mathrm{~min}$ duration, and of focal seizures, an epileptic activity persisting for $>10 \mathrm{~min}$ (1). The danger of prolonged seizure is seizure-related irreversible neuronal damage ${ }^{(3,4)}$.

Several studies have addressed important aspects of $\mathrm{SE}$ in terms of its etiology and incidence. Both the incidence of SE and SE-related mortality vary greatly, ranging from 5.2 to 12.4 per $100,000{ }^{(5)}$. In a 2017 meta-analysis, new onset of symptomatic etiology was reported to be the leading cause of etiologyspecific SE (odds ratio [OR]: 0.411; 95\% confidence interval [Cl]: 0.315-0.507) ${ }^{(6)}$. SE may be the condition underlying several neurologic disorders, including epileptic syndromes, rather than a syndrome or disease in itself ${ }^{(7)}$. The most prevalent cause of SE in children is febrile seizure, but fever may also be the triggering factor in patients with previously diagnosed epilepsy ${ }^{(8)}$. The other causes of SE are abnormalities as seen on neuroimaging, inborn errors of metabolism, electrolyte imbalances, intoxication, central nervous system (CNS) infections, and autoimmune disorders ${ }^{(9)}$.

Immediate therapy plays a crucial role in seizure termination, as mortality may otherwise reach $22 \%$ $(7,10)$. Almost $80 \%$ of seizures are successfully managed by first-line anti-seizure drugs ${ }^{(11)}$, but in the remaining $20 \%$, seizure activity may fail to cease in response to first- or second-line therapies (benzodiazepine and anticonvulsive drugs) and will progress to refractory SE (RSE).
Super RSE (SRSE) is defined as the persistence of seizure activity for $>24 \mathrm{~h}$ and requires the administration of general anesthesia drugs ${ }^{(12,13)}$. The annual incidence of SE is 12-23 episodes per 100,000 children, with $10-40 \%$ developing RSE ${ }^{(14,15)}$. The incidence of SRSE reported in 602 convulsive children was $7.14 \%^{(16)}$. However, neurological complications are not the only concern in the management of convulsive children. Even if many SRSE episodes are successfully managed with aggressive anti-seizure therapy, the typically prolonged pediatric intensive care unit (PICU) stay may lead to secondary complications of infections, drug-related adverse effects, or hematologic complications (17). Consequently, predicting the risk of SRSE is of paramount importance in PICU management. The current study analyzed PICU admissions in children with prolonged seizures, including a risk analysis for subsequent SRSE. The demographic and clinical features, underlying etiologies, treatment modalities, electroencephalography (EEG) and neuroimaging findings, and metabolic states of the children prior to PICU admission were therefore evaluated.

\section{PATIENTS AND METHODS}

The study protocol was approved by the local ethics committee and followed the principles for human investigations outlined in the Second Declaration of Helsinki (date, April 17, 2019; no.: 2019-04/02). Parental consent for study participation was not required due to its retrospective design.

The study was conducted at the Sivas Cumhuriyet University Faculty of Medicine. The hospital includes a level-III, high-volume-referral intensive care unit with 8-bed capacity (600-750 admissions / per year) for the densely populated territory around the central Anatolia region. All intensive care admissions manifesting prolonged seizure (seizure lasting more than five minutes that occur either at the emergency room, pediatric ward or during PICU stay) between January 2014 and January 2019 were enrolled in the study. Demographic and other data, including those on underlying chronic conditions, history of epilepsy, and anti-seizure medications, were extracted from the electronic database. Data on seizure etiology, duration of seizure prior to PICU admission, metabolic state at initial PICU admission, and clinical 
features, including endotracheal intubation, PRISM3 score, treatment modalities, EEG monitoring, and CNS neuroimaging were collected. Etiologic factors for seizures were classified as: i) withdrawal of the antiepileptic drug, ii) fever (meningitis/encephalitis or infections other than those of the CNS), iii) intoxications, and iv) structural abnormalities of the CNS.

The group categorizations were based on the presence of fever (seizures with and without fever) and a newonset seizure (children with a history of epilepsy vs. those with a new- onset seizure). Children progressing to SRSE were identified, and their data analyzed accordingly.

Abnormal biochemical features were identified in laboratory tests of venous blood samples or blood gas analysis at initial PICU admission, including hyponatremia (serum sodium <135 meq/L) (18), hypoglycemia (serum blood glucose $<60 \mathrm{mg} / \mathrm{dL}$ ), hypocalcemia (serum calcium $<8.5 \mathrm{mg} / \mathrm{dL}$ and blood gas ionized calcium $<1 \mathrm{mmol} / \mathrm{L}$ ), elevated lactate (blood gas lactate $>2 \mathrm{mmol} / \mathrm{L}$ ), and metabolic acidosis (blood gas $\mathrm{pH}<7.35, \mathrm{HCO}_{3}<15 \mathrm{meq} / \mathrm{L}, \mathrm{BE}>-5$ ).

In the absence of continuous EEG monitoring in the PICU, EEG monitoring was conducted twice a day (30$45 \mathrm{~min} /$ session). The recording data were analyzed according to epileptic activity (generalized vs. focal), background activity (normal vs. abnormal), and the acquired burst-suppression pattern. Neuroimaging, either computed tomography (CT) or magnetic resonance imaging (MRI) was conducted before discharge.

\section{Statistical analysis}

SPSS version 22 (IBM Corporation, Armonk, NY, USA) was used for the statistical analysis. Descriptive variables were expressed as percentages (\%), the means \pm standard deviation, or medians with interquartile ranges (IQRs) in parentheses. A chisquared or Fisher's exact test was used for categorical variables, and Student's t-test or a Mann Whitney U-test for quantitative data following an assessment of normality in a Kolmogorov-Smirnov test. Logistic regression analysis was performed to analyze the risk of acquiring SRSE. A p-value $<0.05$ indicated statistical significance.

\section{RESULTS}

Of the 71 children enrolled in the study, 53.5\% were male and the median age was 59 months (IQR, 22-115 months). Forty-five children had pre-existing epilepsy and $28.2 \%$ had been prescribed daily medications consisting of multiple antiepileptic drugs. Tables 1 and 2 present the demographic data, antiepileptic medications, and seizure-triggering factors. The major cause of seizure was fever in $45.1 \%$ (CNS infections confirmed by spinal fluid investigations in $16.9 \%$ and infections other than CNS in 28.2\%), withdrawal of antiepileptic medications in $40.9 \%$, intoxication in $12.7 \%$ of children and intracranial hemorrhage due to arteriovenous malformation in one patient (1.4\%). The median onset of seizure until PICU admission was 20 (IQR, 12.5-30) minutes. The initial work-up of metabolic status revealed hypoglycemia in $23.9 \%$, hypocalcemia in $18.3 \%$, hyponatremia in $15.5 \%$, acidosis in $35.2 \%$, and an elevated lactate level in $25.4 \%$ of the patients. Three $(4.2 \%)$ patients died due to secondary complications of seizure. Fever at the initial onset of seizure occurred in $45.1 \%$ of the study population and more often in younger children $(p=0.023)$. The

Tablo 2. Triggering Factors and Anticonvulsive Medications of the study population.

\begin{tabular}{|lc|}
\hline \multicolumn{1}{|c|}{ Seizure triggering factor } & \\
\hline Medication withdrawal & $29(40.9 \%)$ \\
\hline Seizures with fever & $32(45.1 \%)$ \\
\hline \multicolumn{1}{|c|}{ Meningitis/encephalitis } & $12(16.9 \%)$ \\
\hline $\begin{array}{l}\text { Infection not involving central nervous } \\
\text { system }\end{array}$ & $20(28.2 \%)$ \\
\hline Intoxicity & $9(12.7 \%)$ \\
\hline Intracranial hemorrhage* & $1(1.4 \%)$ \\
\hline \multicolumn{1}{|c|}{ Anti-seizure medications of } & \\
\hline \multicolumn{1}{|c|}{ epileptic children } & $20(28.2 \%)$ \\
\hline Multi-drug anticonvulsive medications & $24(33.8 \%)$ \\
\hline Levetiracetam & $18(25.4 \%)$ \\
\hline Valproic acid & $11(15.5 \%)$ \\
\hline Phenobarbital & $2(2.8 \%)$ \\
\hline Carbamazepine & $6(8.5 \%)$ \\
\hline Oxcarbamazepine & $3(4.2 \%)$ \\
\hline Clonazepam & $3(4.2 \%)$ \\
\hline Vigabatrin & $1(1.4 \%)$ \\
\hline Lamotrigine & $1(1.4 \%)$ \\
\hline Topiramate & $6(8.5 \%)$ \\
\hline Clobazam & \\
\hline
\end{tabular}

*Hemorrhage due to arteriovenous malformation 
Table 1. Demographics and clinical outcome based on fever.

\begin{tabular}{|c|c|c|c|c|}
\hline n (\%) & $\begin{array}{c}\text { Overall } \\
\text { (71) }\end{array}$ & $\begin{array}{c}\text { Seizure with fever } \\
(n=32)\end{array}$ & $\begin{array}{l}\text { Seizure without fever } \\
\qquad(n=39)\end{array}$ & $\mathbf{P}$ \\
\hline Age (months) * & $59(22-115)$ & $40(23-112)$ & $63(7-168)$ & 0.023 \\
\hline Weight $(\mathrm{kg}) *$ & $15(9.5-28.0)$ & $15(10-31)$ & $15.5(8.4-28.7)$ & 0.989 \\
\hline Male gender & 38 (53.5\%) & 19 (59.4\%) & 19 (48.7\%) & 0.370 \\
\hline Sibling death & $11(15.5 \%)$ & $6(18.8 \%)$ & $5(12.8 \%)$ & 0.359 \\
\hline The underlying condition & $48(67.6 \%)$ & 25 (78.1\%) & $23(59 \%)$ & 0.086 \\
\hline $\begin{array}{l}\text { Neurological etiology } \\
\text { (other than epilepsy) }\end{array}$ & 22 (31\%) & $12(48 \%)$ & $10(43.5 \%)$ & \\
\hline Metabolic & $8(11.3 \%)$ & $4(16 \%)$ & $4(17.4 \%)$ & \\
\hline Cardiac & $4(5.6 \%)$ & $3(12 \%)$ & $1(4.3 \%)$ & \\
\hline Chronic lung disease & $2(2.8 \%)$ & $2(8 \%)$ & - & 0.494 \\
\hline Malignancy & $1(1.4 \%)$ & $1(4 \%)$ & - & \\
\hline Hematological & $1(1.4 \%)$ & - & $1(4.3 \%)$ & \\
\hline Immune deficiency & $1(1.4 \%)$ & - & $1(4.3 \%)$ & \\
\hline Endocrinologic & $7(9.9 \%)$ & $2(8 \%)$ & $5(21.7 \%)$ & \\
\hline Renal & $2(2.8 \%)$ & $1(4 \%)$ & $1(4.3 \%)$ & \\
\hline Previous hospitalization & $59(83.1 \%)$ & $28(87.5 \%)$ & $31(79.5 \%)$ & 0.370 \\
\hline History of epilepsy & $45(63.4 \%)$ & $17(53.1 \%)$ & $28(71.8 \%)$ & 0.104 \\
\hline $\begin{array}{l}\text { Multi-drug seizure medica- } \\
\text { tion }\end{array}$ & $20(28.2 \%)$ & $7(21.9 \%)$ & $13(33.3 \%)$ & 0.286 \\
\hline $\begin{array}{l}\text { Number of seizures prior } \\
\text { to ICU admission* }\end{array}$ & $2(1-4)$ & $3(1-4.5)$ & $2(1-3)$ & 0.219 \\
\hline $\begin{array}{l}\text { Length of seizures prior to } \\
\text { ICU admission (minutes)* }\end{array}$ & $20(12.5-30)$ & $20(15-37.5)$ & $22.5(10-30)$ & 0.686 \\
\hline \multicolumn{5}{|c|}{ PICU follow-up } \\
\hline Hyponatremia & $11(15.5 \%)$ & $6(18.8 \%)$ & $5(12.8 \%)$ & 0.359 \\
\hline Hypoglycemia & $17(23.9 \%)$ & $8(25 \%)$ & $9(23.1 \%)$ & 0.850 \\
\hline Hypocalcemia & $13(18.3 \%)$ & 7 (21.9\%) & $6(15.4 \%)$ & 0.482 \\
\hline Metabolic acidosis & $25(35.2 \%)$ & $6(18.7 \%)$ & $19(48.7 \%)$ & 0.027 \\
\hline Elevated lactate & $18(25.4 \%)$ & $8(25.0 \%)$ & $10(25.6 \%)$ & 0.951 \\
\hline Midazolam infusion & $28(39.4 \%)$ & $15(46.9 \%)$ & $13(33.3 \%)$ & 0.245 \\
\hline Sodium-Pentothal infusion & $12(16.9 \%)$ & $6(18.8 \%)$ & $6(15.4 \%)$ & 0.707 \\
\hline \multicolumn{5}{|c|}{ EEG monitoring } \\
\hline $\begin{array}{l}\text { Abnormality of back- } \\
\text { ground activity }\end{array}$ & $17(23.9 \%)$ & $6(18.75 \%)$ & $11(28.2 \%)$ & 0.539 \\
\hline Epileptic abnormality & $44(62.0 \%)$ & $21(65.6 \%)$ & $23(58.9 \%)$ & 0.515 \\
\hline Burst supression & $12(8.5 \%)$ & $6(18.8 \%)$ & $6(15.4 \%)$ & 0.707 \\
\hline Focal epileptic abnormality & $22(31.0 \%)$ & $10(32.3 \%)$ & $12(30.8 \%)$ & 0.894 \\
\hline $\begin{array}{l}\text { Generalized epileptic } \\
\text { abnormality }\end{array}$ & $16(22.5 \%)$ & $8(25 \%)$ & $8(20.5 \%)$ & 0.653 \\
\hline Neuroimaging & $26(36.6 \%)$ & $8(25 \%)$ & $18(46.2 \%)$ & 0.627 \\
\hline $\begin{array}{l}\text { Abnormality at neuroim- } \\
\text { aging }\end{array}$ & $16(22.5 \%)$ & $7(21.8 \%)$ & $9(23.1 \%)$ & 0.185 \\
\hline \multicolumn{5}{|c|}{ Outcome } \\
\hline PRISM-3 score * & $1(1-5)$ & $1(1-5)$ & $1(1-5)$ & 0.459 \\
\hline Endotracheal intubation & $28(39.4 \%)$ & $12(37.5 \%)$ & $16(41 \%)$ & 0.762 \\
\hline Tracheostomy & $5(7.0 \%)$ & $4(12.5 \%)$ & $1(2.6 \%)$ & 0.123 \\
\hline Gastrostomy & $10(14.1 \%)$ & 7 (21.9\%) & $3(7.7 \%)$ & 0.086 \\
\hline $\begin{array}{l}\text { Length of PICU stay } \\
\text { (days)* }\end{array}$ & $7(6-10)$ & $7(6-10.75)$ & $7(5-9)$ & 0.608 \\
\hline $\begin{array}{l}\text { Length of hospitalization } \\
\text { (days)* }\end{array}$ & $12(11-13)$ & $12(11-13)$ & $12(11-13)$ & 0.598 \\
\hline Mortality & $3(4.2 \%)$ & $2(6.3 \%)$ & $1(2.6 \%)$ & 0.425 \\
\hline
\end{tabular}

*median (interquartile range) 
demographic features and underlying chronic conditions were mostly similar between children with and without fever (Table 1). Fifteen (46.9\%) children with fever required intravenous midazolam infusions and six (18.8\%), received thiopental-sodium infusions to induce a burst-suppression pattern. As neurological complication, inability to tolerate airway maneuvers necessitated tracheostomy cannulation in $12.5 \%$ of the patients.

Table 3 summarizes the demographic features and clinical outcomes of new- onset seizures. Epileptic children were older and more likely to have a history of sibling death $(p=0.023$ and $p=0.036$, respectively), whereas a neuroimaging abnormality was detected in $57.5 \%$ of patients with a new- onset seizure $(p=0.034)$. These patients also had a significant elevation of the lactate level and acidosis and more frequently required invasive respiratory support $(p=0.017, p=0.002$, and $p=0.008$, respectively), even if the duration and frequency of seizures were similar between the two groups ( $p=0.194$ and $p=0.880$, respectively).

In 12 children (16.9\%), prolonged seizures progressed to SRSE and necessitated thiopental-sodium infusion (Table 4). Fever occurred in 50\% of the SRSE patients with viral encephalitis (herpes simplex in two children; the cause of infection could not be identified in the third patient). The withdrawal of antiepileptic medication was defined as the second-most common etiology (33.3\%). Two adolescents suffered SRSE due to multidrug abuse of tricyclic antidepressants and amphetamine overdose. Seizure duration prior to PICU admission was significantly longer in children with SRSE (median, 30 min; IQR, 23.75-60 min; $p=0.002$ ). Low serum sodium (OR, 10.800; 95\% Cl, 2.518-46.318) and calcium levels (OR, 4.554; 95\% Cl, 1.159-17.892) were associated with SRSE development (Table 5); however, in the multivariate regression model, which included fever, new onset of disease, hyponatremia, hypocalcemia, hypoglycemia, and the PRISM-3 score, only the PRISM-3 score was identified as the independent risk factor for progressing to SRSE (OR, 1.174; 95\% Cl, 1.039-1.327; $p=0.010)$.

\section{DISCUSSION}

In pediatric patients, SE is a common, life-threatening neurological emergency ${ }^{(19)}$ often requiring intensive care management. Moreover, the development of secondary complications, especially infection, the need for endotracheal intubation, and anticonvulsive drug-related adverse effects, may lead to increased morbidity and mortality. The goal of therapy with anticonvulsive medications is to terminate the seizure as early as possible, before the development of irreversible brain damage. Thus, the ability to predict which patients will progress to SRSE and thereby initiate timely preventive measures is of paramount importance. Our study investigated children with prolonged seizure who were admitted to one of the largest referral PICUs in Anatolia, Turkey. The major findings of this descriptive study were: i) anticonvulsive drug withdrawal and infections other than those involving CNS were the main seizure-triggering factors $(40.9 \%$ and $28.2 \%$, respectively), ii) seizure with fever occurred in $45.1 \%$ of the study population and at a younger age (median, 40 months); iii) children with new-onset seizure exhibited significant hemodynamic abnormalities, mostly an elevated lactate level and acidosis, iv) patients with a history of epilepsy were older and had a history of sibling death; v) low serum sodium and calcium levels were associated with SRSE and vi) the PRISM-3 score was the sole independent risk factor for progression to SRSE (OR, 1.174; 95\% Cl, 1.039-1.327).

Among the risk factors for SE morbidity (age, etiology, and duration of seizure), etiologic factors have the utmost importance ${ }^{(1,20-23)}$. The incidence rates of SE in epileptic children ranges from $34 \%$ to $53.3 \%{ }^{(24,25)}$. The percentage of epileptic children in our study was slightly higher (63.4\%), and drug withdrawal was identified as the major determinant of prolonged seizure in these patients $(40.9 \%)$. In a study of children with new-onset seizure, fever was the most prevalent cause (57.7\%). Lacroix et al. reported similar findings regarding seizure etiology as an epilepsy background in $45.6 \%$ of their study population and febrile seizure was the most frequent cause of SE ${ }^{(25)}$. In another study based on a large dataset derived from 13 hospitals, febrile seizures were detected in $12 \%$ of 1679 hospital admissions ${ }^{(26)}$.

Similar to the results of previous studies, sex was not a determining factor despite the higher percentage of males in our study population (female-to-male ratio, $1: 1.15)^{(27,28)}$. Previous reports on SE included patients 
Table 3. Demographics of new- onset seizures

\begin{tabular}{|c|c|c|c|c|}
\hline n (\%) & $\begin{array}{l}\text { Overall } \\
(n=71)\end{array}$ & $\begin{array}{c}\text { Epilepsy history } \\
(n=32)\end{array}$ & $\begin{array}{l}\text { New onset of seizure } \\
(n=39)\end{array}$ & $\mathbf{p}$ \\
\hline Age (months) * & $59(22-115)$ & $63(20.5-122.5)$ & $40.5(22.75-98.50)$ & 0.023 \\
\hline Weight $(\mathbf{k g}) *$ & $15(9.5-28.0)$ & $15(8.9-26.25)$ & $16(10.25-36.50)$ & 0.989 \\
\hline Male gender & $38(53.5 \%)$ & $25(55.6 \%)$ & $13(50.0 \%)$ & 0.651 \\
\hline Death of a Sibling & $11(15.5 \%)$ & $10(22.2 \%)$ & $1(3.8 \%)$ & 0.036 \\
\hline The underlying conditions & $48(67.6 \%)$ & $25(55.6 \%)$ & $23(88.5 \%)$ & 0.004 \\
\hline $\begin{array}{l}\text { Neurologic (other than epilep- } \\
\text { sy) }\end{array}$ & $22(31 \%)$ & $14(56 \%)$ & $8(34.8 \%)$ & \\
\hline Metabolic & $8(11.3 \%)$ & $5(20 \%)$ & $3(13 \%)$ & \\
\hline Cardiac & $4(5.6 \%)$ & $1(4 \%)$ & $3(13 \%)$ & \\
\hline Chronic lung disease & - & $3(8.7 \%)$ & - & 0.214 \\
\hline Malignancy & $1(1.4 \%)$ & $1(4 \%)$ & - & \\
\hline Hematological & $1(1.4 \%)$ & - & $1(4.3 \%)$ & \\
\hline Immune deficiency & $1(1.4 \%)$ & - & $1(4.3 \%)$ & \\
\hline Endocrinologic & $7(9.9 \%)$ & $2(8 \%)$ & $5(21.7 \%)$ & \\
\hline Renal & $2(2.8 \%)$ & - & $2(4.2 \%)$ & \\
\hline Previous hospitalization & $59(83.1 \%)$ & $37(82.2 \%)$ & $22(84.6 \%)$ & 0.536 \\
\hline $\begin{array}{l}\text { Multi-drug anticonvulsive medi- } \\
\text { cation }\end{array}$ & $20(18.3 \%)$ & $20(44.4 \%)$ & - & - \\
\hline $\begin{array}{l}\text { No. of seizure prior to ICU admis- } \\
\text { sion* }\end{array}$ & $1(1-3)$ & $1(1-3)$ & $1(1-2)$ & 0.880 \\
\hline $\begin{array}{l}\text { Duration of seizure prior to ICU } \\
\text { (minutes)* }\end{array}$ & $20(12.5-30)$ & $20(10-30)$ & $27.5(16.25-56.25)$ & 0.194 \\
\hline \multicolumn{5}{|l|}{ Seizure triggering factor } \\
\hline Medication withdrawal & $29(40.9 \%)$ & $29(64.4 \%)$ & - & - \\
\hline Fever & $32(45.1 \%)$ & $17(37.8 \%)$ & $15(57.7 \%)$ & 0.496 \\
\hline Meningitis/encephalitis & $12(16.9 \%)$ & $7(15.6 \%)$ & $5(19.2 \%)$ & 0.464 \\
\hline Infections not involving CNS** & $20(28.2 \%)$ & $10(22.2 \%)$ & $10(38.5 \%)$ & 0.143 \\
\hline Toxicity & $9(12.7 \%)$ & - & $9(34.6 \%)$ & - \\
\hline Intracranial hemorrhage & $1(1.4 \%)$ & - & $1(3.8 \%)$ & - \\
\hline \multicolumn{5}{|l|}{ PICU follow-up } \\
\hline Hyponatremia & $11(15.5 \%)$ & $7(15.6 \%)$ & $4(15.4 \%)$ & 0.633 \\
\hline Hypoglycemia & $17(23.9 \%)$ & $9(20 \%)$ & $8(30.8 \%)$ & 0.306 \\
\hline Hypocalcemia & $13(18.3 \%)$ & $11(24.4 \%)$ & $2(7.7 \%)$ & 0.071 \\
\hline Metabolic acidosis & $25(35.2 \%)$ & $5(19.2 \%)$ & $20(44.4 \%)$ & 0.008 \\
\hline Elevated lactate & $18(25.4 \%)$ & $5(11.1 \%)$ & $13(54.1 \%)$ & 0.002 \\
\hline Midazolam infusion & $28(39.4 \%)$ & $20(44.4 \%)$ & $8(30.8 \%)$ & 0.256 \\
\hline Sodium-Pentothal infusion & $12(16.9 \%)$ & $8(17.8 \%)$ & $4(15.4 \%)$ & 0.536 \\
\hline \multicolumn{5}{|l|}{ EEG monitoring } \\
\hline Abnormal background activity & $17(23.9 \%)$ & $12(26.6 \%)$ & $5(19.2 \%)$ & 0.648 \\
\hline Epileptic abnormality & $44(62.0 \%)$ & $33(73.3 \%)$ & $11(42.3 \%)$ & 0.104 \\
\hline Burst supression & $12(16.9 \%)$ & $8(17.8 \%)$ & $4(15.4 \%)$ & 0.536 \\
\hline Focal epileptic abnormality & $22(31.0 \%)$ & $14(31.8 \%)$ & $8(30.8 \%)$ & 0.927 \\
\hline $\begin{array}{l}\text { Generalized epileptic abnormali- } \\
\text { ty }\end{array}$ & $16(22.5 \%)$ & $13(28.9 \%)$ & $3(11.5 \%)$ & 0.092 \\
\hline Neuroimaging & $26(36.6 \%)$ & $12(26.6 \%)$ & $14(53.8 \%)$ & 0.034 \\
\hline Abnormality at neuroimaging & $16(22.5 \%)$ & $11(24.4 \%)$ & $5(19.2 \%)$ & 0.567 \\
\hline \multicolumn{5}{|l|}{ Outcome } \\
\hline PRISM-3 score* & $1(1-5)$ & $1(1-5)$ & $1(1-5.25)$ & 0.593 \\
\hline Endotracheal intubation & $28(39.4 \%)$ & $13(28.9 \%)$ & $15(57.7 \%)$ & 0.017 \\
\hline Tracheostomy & $5(7.0 \%)$ & $3(6.7 \%)$ & $2(7.7 \%)$ & 0.609 \\
\hline Gastrostomy & $10(14.1 \%)$ & $7(15.6 \%)$ & $3(11.5 \%)$ & 0.464 \\
\hline Length of PICU stay (days)* & $7(6-10)$ & $7(6-11)$ & $6(5-7.25)$ & 0.201 \\
\hline Length of hospitalization (days)* & $12(11-13)$ & $12(11-13)$ & $12(10.75-13)$ & 0.573 \\
\hline Mortality & $3(4.2 \%)$ & $1(2.2 \%)$ & $2(7.7 \%)$ & 0.301 \\
\hline
\end{tabular}

${ }^{*}$ median (interquartile range), ${ }^{* *}$ CNS: central nervous system 
ranging in age from 1 to 6.5 years ${ }^{(25,28,29)}$, whereas the median age of SE children in our study was 59 months (IQR, 22-115 months). In the group with febrile SE, the median age was lower, 40 months. Because younger children are more susceptible to infections, febrile SE has a tendency to occur at younger ages (40 vs. 63 months for epileptic children, $p=0.023$ ). Thus, our finding regarding the older age of children with febrile $\mathrm{SE}$ is in contrast to those of previous investigations in which the age range was $14-23$ months ${ }^{(8,20,30-36)}$. This discrepancy may reflect socio-cultural differences in early childhood education and care. According to the 2019 Organization for Economic Cooperation and Development (OECD) report, early childhood education and care in children aged $0-2$ years is provided at a rate of $1 \%$ in Turkey, a much lower rate than in other OECD countries, where it is as high as $60 \%{ }^{(37)}$. In Turkey, caring for children at home by a parent or an elderly relative is much more common, such that the risk of encountering infections and febrile SE at a younger age is reduced.

Few studies have investigated the effect of seizure on metabolism ${ }^{(38)}$. Lactate is the end-product of anaerobic glycolysis. In cellular hypoxia, an adaptive process emerges to generate energy but at the cost of worsening acidosis and the degradation of pyruvate to lactate ${ }^{(39)}$. Hypoxia also explains why lactate elevation occurs in tonic-clonic seizures, during which catecholamines are discharged and metabolic alterations in muscle contribute to lactate elevation. Matz et al. reported significantly increased lactate levels during generalized tonic-clonic seizures and suggested that lactate levels during seizures could be used to distinguish psychogenic non-epileptic and syncopal events (38). Our findings provide support for this hypothesis, as the metabolic state was altered in our patients with prolonged seizure, including metabolic acidosis (35.2\%) and lactate elevation (25.4\%). Interestingly, although the seizure duration prior to PICU admission was similar between children with a new- onset seizure and epileptic patients, significant metabolic abnormalities in the form of lactate elevation ( $p=0.002)$ and acidosis $(p=0.008)$ were detected in the new-onset seizure patients via initial blood gas analysis. Moreover, these patients more often required invasive respiratory support. Neurophysiological studies are needed to determine whether this condition is a coincidence or a hemostatic adaptation. Nonetheless, anyone experiencing seizure, regardless of the epileptic background, should be closely monitored and treated accordingly.

Acute metabolic disturbances of glucose, calcium, and sodium may lead to recurrent or prolonged seizures ${ }^{(40,41)}$. If left untreated, they can result in permanent brain tissue injury ${ }^{(18)}$. Clinical and experimental studies have shown that hyponatremia is a triggering factor in convulsion ${ }^{(42-44)}$. In a child manifesting an afebrile seizure, the American Academy of Neurology recommends screening for electrolyte anomalies, especially hyponatremia, which is a common cause of acute afebrile seizure in children ${ }^{(45)}$. A patient is considered hyponatremic if the serum sodium level is $<135 \mathrm{meq} / \mathrm{L}$, and severely hyponatremic if the level is $<125 \mathrm{meq} / \mathrm{L}^{(18)}$. Brain swelling and seizures related to a low sodium level are more likely to develop if the level falls to $115 \mathrm{meq} / \mathrm{L}$. However, a patient with electrolyte disturbances at acute onset is more likely to develop seizures. However, defining the absolute levels of electrolyte abnormality likely to induce seizure is difficult ${ }^{(46)}$. Moreover the larger brain-to-skull size ratio makes children more prone to developing symptomatic hyponatremia ${ }^{(18)}$. In the current study, patients were considered hyponatremic if the serum sodium level was $<135 \mathrm{meq} / \mathrm{L}$. According to the univariate analysis, following the initiation of a seizure, a decrease in the serum sodium level less than $135 \mathrm{meq} / \mathrm{L}$ increases the odds of developing SRSE 10.8-fold. How hyponatremia triggers a seizure could not be further investigated, because laboratory data were obtained only after PICU admission and not before. However, low sodium levels may increase the risk of continuing seizure, thus leading to SRSE progression, even in cases with hyponatremia ( $\mathrm{Na}<135 \mathrm{meq} / \mathrm{L}$ ). The results of our study are concordant with those of a previous study of children with gastroenteritis and seizure, who found that even mild hyponatremia ( $\mathrm{Na}=126-134 \mathrm{meq} / \mathrm{L}$ ) can affect the duration of seizure and thereby, increase the risk of SE (47). By contrast, Holtkamp et al. reported that low sodium levels cannot be the sole factor initiating seizure even if patients with RSE frequently experience hyponatremia (serum sodium level <135meq/L) compared to those with non-RSE ${ }^{(48)}$. Another study has also reported that low sodium levels are not related to seizure alone, but it occurs as a consequence of thiopental infusion due to drug-related volumedependent antidiuretic hormone secretion ${ }^{(49)}$. In critically ill children, excessive secretion of arginine vasopressin results in free water retention, and the risk of hyponatremia can be exacerbated by the administration 
Table 4. Demographics and clinical outcomes of super-refractory SE

\begin{tabular}{|c|c|c|c|}
\hline N (\%) & $\begin{array}{c}\text { Super-refractory SE } \\
(\mathrm{n}=12)\end{array}$ & $\begin{array}{c}\text { Seizures } \\
(n=59)\end{array}$ & $\mathbf{p}$ \\
\hline Age (months) * & $69(19.5-149.75)$ & $50(22-103)$ & 0.771 \\
\hline Weight (kg) * & $16(10.5-28)$ & $15(9.125-30)$ & 0.644 \\
\hline Male gender & $8(66.7 \%)$ & $30(50.8 \%)$ & 0.317 \\
\hline Sibling death & $4(33.3 \%)$ & $7(11.9 \%)$ & 0.082 \\
\hline The underlying conditions & $7(58.3 \%)$ & $41(69.5 \%)$ & 0.332 \\
\hline Neurological & $4(57.1 \%)$ & $18(43.9 \%)$ & \\
\hline Metabolic & $3(42.9 \%)$ & $5(12.2 \%)$ & \\
\hline Cardiac & - & $4(9.8 \%)$ & \\
\hline Chronic lung disease & - & $2(4.9 \%)$ & 0.085 \\
\hline Malignancy & - & $1(2.4 \%)$ & \\
\hline Hematological & - & $1(4.3 \%)$ & \\
\hline Immune deficiency & - & $1(2.4 \%)$ & \\
\hline Endocrinologic & - & $7(17.1 \%)$ & \\
\hline Renal & - & $2(4.9 \%)$ & \\
\hline Previous hospitalization & $11(91.7 \%)$ & $48(81.4 \%)$ & 0.350 \\
\hline Previous epilepsy history & $8(66.7 \%)$ & $37(62.7 \%)$ & 0.536 \\
\hline $\begin{array}{l}\text { Duration of seizure prior to ICU } \\
\text { admission }\end{array}$ & $30(23.75-60)$ & $15(10-30)$ & 0.003 \\
\hline Abnormality at neuroimaging & $5(83.3 \%)$ & $7(33.3 \%)$ & 0.002 \\
\hline Multi-drug epilepsy medication & $5(41.7 \%)$ & $15(25.4 \%)$ & 0.212 \\
\hline Levetiracetam & $5(41.7 \%)$ & $19(32.2 \%)$ & 0.375 \\
\hline Valproic acid & $3(25 \%)$ & $15(25.4 \%)$ & 0.643 \\
\hline Phenobarbital & $3(25 \%)$ & $8(13.6 \%)$ & 0.272 \\
\hline Carbamazepine & $1(8.3 \%)$ & $1(1.7 \%)$ & 0.831 \\
\hline Oxcarbamazepine & $2(16.7 \%)$ & $4(6.8 \%)$ & 0.266 \\
\hline Clonazepam & $2(16.7 \%)$ & $1(1.7 \%)$ & 0.072 \\
\hline Vigabatrin & $1(8.3 \%)$ & $2(3.4 \%)$ & 0.431 \\
\hline Lamotrigine & - & $1(1.7 \%)$ & 0.831 \\
\hline Topiramate & - & $1(1.7 \%)$ & 0.831 \\
\hline Clobazam & $1(8.3 \%)$ & $5(8.5 \%)$ & 0.734 \\
\hline \multicolumn{4}{|l|}{ Triggering factors } \\
\hline Medication withdrawal & $4(33.3 \%)$ & 25 (342.4\%) & 0.403 \\
\hline Fever & $6(50 \%)$ & $27(45.8 \%)$ & 0.474 \\
\hline CNS infection & $3(25 \%)$ & $9(15.3 \%)$ & 0.326 \\
\hline Infections not involving CNS & $3(25 \%)$ & $17(28.8 \%)$ & 0.547 \\
\hline Toxicity** & $2(16.7 \%)$ & $7(11.9 \%)$ & 0.474 \\
\hline Intracranial hemorrhage & - & $1(1.7 \%)$ & - \\
\hline \multicolumn{4}{|l|}{ PICU follow-up } \\
\hline Hypoglycemia & $2(16.7 \%)$ & $15(25.4 \%)$ & 0.408 \\
\hline Hypocalcemia & $5(41.7 \%)$ & $8(13.6 \%)$ & 0.036 \\
\hline Hyponatremia & $6(50 \%)$ & $5(8.5 \%)$ & 0.002 \\
\hline Metabolic acidosis & $6(50 \%)$ & $19(32.2 \%)$ & 0.014 \\
\hline Lactate elevation & $7(58.3 \%)$ & $11(18.6 \%)$ & 0.008 \\
\hline \multicolumn{4}{|l|}{ Outcome } \\
\hline PRISM-3 score * & $10(1.25-14.75)$ & $1(1-4)$ & 0.003 \\
\hline Tracheostomy & $2(16.7 \%)$ & $3(5.1 \%)$ & 0.196 \\
\hline Length of PICU stay (days) * & $24(15.5-27.5)$ & $6(5-8)$ & $<0.001$ \\
\hline Length of hospitalization (days)* & $33(25.75-48.75)$ & $11(11-12)$ & $<0.001$ \\
\hline Mortality & $3(25 \%)$ & - & NA \\
\hline
\end{tabular}

${ }^{*}$ median (interquartile range), ${ }^{* *}$ toxicity: multi-drug abuse of tricyclic antidepresants and amphetamin overdose 
Tablo 5. Univariate logistic regression model for super-refractory status epilepticus.

\begin{tabular}{|c|c|c|c|c|}
\hline & \multicolumn{3}{|c|}{ 95\% Cl } & Upper Limit \\
\hline & Odds Ratio & Lower limit & & \\
\hline Fever & & & 4.398 & 0.707 \\
\hline New- onset seizure & 1.269 & 0.366 & 3.120 & 0.796 \\
\hline Hyponatremia & 0.841 & 0.227 & 46.318 & $\mathbf{0 . 0 0 1}$ \\
\hline Hypocalcemia & 10.800 & 2.518 & 17.892 & $\mathbf{0 . 0 3 0}$ \\
\hline Hypoglycemia & 4.554 & 1.159 & 2.986 & 0.521 \\
\hline PRISM-3 score & 0.587 & 0.115 & 1.379 & $\mathbf{0 . 0 0 3}$ \\
\hline
\end{tabular}

of hypotonic fluids. Therefore, since the early 2000s, the administration of isotonic fluids in the form of saline $(0.09 \% \mathrm{NaCl}$ solution) and dextrose has been recommended as maintenance fluid therapy ${ }^{(45-47)}$. Again, we recommend that health-care providers supply isotonic solutions to convulsive children, unless medically indicated, as maintaining serum sodium levels within a normal range is crucial to terminating the seizure as early as possible.

Critically-ill children requiring intensive care often exhibit abnormal EEG features, an increased risk of seizure, and neurological deterioration ${ }^{(50)}$. Seizure is also observed as one of the short-term outcomes in very sick children ${ }^{(51)}$. The PRISM-3 score predicts the risk of mortality in children, based on the severity of illness according to abnormalities in 17 physiological variables as assessed via physical examination and laboratory tests within 24 hs of intensive care unit admission ${ }^{(52)}$. In our study the multivariable logistic regression analysis identified the PRISM-3 score as the sole independent risk factor for progressing to SRSE, but this finding must be interpreted cautiously because the score is calculated from values recorded on the first day of intensive care unit admission, which are likely to be the worst. Future studies should determine whether the PRISM-3 score is a predictor of SRSE or reflects life-threatening multiorgan system dysfunction as a result of ongoing seizure.

Seizure persisting for $>24 \mathrm{~h}$ after the onset of anesthesia is referred to as SRSE and includes seizure recurrence following a reduction or withdrawal of anesthesia (53). The most common etiology is a history of epilepsy and the development of immune-mediated encephalitis ${ }^{(16)}$. In our study, 28 children (39.4\%) received midazolam infusions (initial dose, $0.1-1 \mathrm{mg} / \mathrm{kg} / \mathrm{h}$ ), 12 of whom (16.9\%) progressed to SRSE despite increased doses of midazolam, and these children subsequently required sodium thiopental infusions. Burst-suppression patterns were observed in the intermittent EEG recordings. Eight of these children had refractory epilepsy and had been receiving multiple antiepileptic medications. In four of them, drug withdrawal was the main cause of prolonged seizure, and the other four had new-onset seizures, including two patients with herpes simplex encephalitis. The underlying etiology could not be identified despite testing for autoimmune diseases.

Neuroimaging was performed in 26 children (36.6\%) within the first day of hospital admission. Abnormalities were detected in $22.5 \%$ but none required surgical intervention. In the study by Sadik et al., $72 \%$ of the patients underwent neuroimaging, with abnormalities detected in $22.8 \%$ of them ${ }^{(54)}$. In the series of Şahin et al., 20 of 45 convulsive patients underwent CT imaging, and $55 \%$ had abnormalities, while 23 patients were examined using cranial MRI, with pathological findings detected in $78.2 \%$ of them ${ }^{(55)}$. The scanning rate of neuroimaging in the present study was far less than relative to those two studies. This difference can be explained by the epileptic profile of the study population, as in our patients the most common cause of seizure was the withdrawal of anti-epileptic drugs, which reduced the necessity of diagnostic neuroimaging.

Three children died of secondary complications (4.2\%), consistent with the rates reported in previous studies, which varied from $3.4 \%$ to $11 \%(56,57)$. In Specchio et al., the mortality rate was $3.5 \%$ in patients in the acute phase of SE and $4.04 \%$ during follow-up. The authors found no evidence of a relationship between age at onset, duration of seizure, and mortality but suggested that mitochondrial disease, cerebral hemorrhage, and CNS malignancies were associated with higher mortality rates ${ }^{(57)}$. 
Our study had several limitations. First, its retrospective design led to a risk of bias. Second, it was performed in a single center with a small number of patients. Both aspects limit the drawing of general conclusions based on the determined outcomes. Third, the study period was restricted to the PICU stage and did not include the preintensive care period. However, our hospital has a level-III, high-volume-referral intensive care unit serving a densely populated region, such that the patients were likely to have been representative of a larger pediatric population with SE. Because all patients with prolonged seizures are transferred to our unit, the clinico-epidemiologic profile of this population could be analyzed in detail.

\section{CONCLUSION}

Prolonged seizures and SE are life-threatening conditions if not immediately treated. Close monitoring is crucial in patients who present with electrolyte imbalances because hyponatremia and hypocalcemia are risk factors for developing SRSE. Therapeutic management consists of timely intervention with anticonvulsive medication and taking the measures necessary to prevent metabolic disturbances.

Ethics Committee Approval: Non-Invasive Research Ethics Committee approval was obtained from Cumhuriyet University (17.04.2019/04/02).

Conflict of Interest: No conflict of interest was declared by the authors.

\section{Funding: None}

Informed Consent: Not required due retrospective design of the study.

\section{REFERENCES}

1. Trinka $E$, Cock $H$, Hesdorffer D, et al. A definition and classification of status epilepticus - Report of the ILAE Task Force on Classification of Status Epilepticus. Epilepsia. 2015;56(10):1515-23. doi: 10.1111/epi.13121.

2. Betjemann JP, Lowenstein $\mathrm{DH}$. Status epilepticus in adults. Lancet Neurol. 2015;14:615-24. doi: 10.1016/S1474-4422(15)00042-3.

3. Devinsky O, Vezzani A, Najjar S, DeLanerolle NC, Rogawski MA. Glia and epilepsy: excitability and inflammation. Trends Neurosci. 2013;36:174-84. doi: 10.1016/j.tins.2012.11.008.

4. Sutter R, Dittrich T, Semmlack S, Rüegg S, Marsch S, Kaplan PW. Acute systemic complications of convulsive status epilepticus - a systematic review. Crit Care Med. 2018;46:138-45. doi: 10.1097/CCM.0000000000002843.

5. Tiamkao S, Pranbul S, Sawanyawisuth K, Thepsuthammarat K, Integrated Epilepsy Research Group. A national database of incidence and treatment outcomes of status epilepticus in
Thailand. Int J Neurosci. 2014;124:416-20. doi: 10.3109/00207454.2013.850084.

6. Lv Rj, Wang Q, Cui T, Zhu F, Shao XQ. Status epilepticus-related etiology, incidence and mortality: A meta-analysis. Epilepsy Res. 2017; 136:12-7. doi: 10.1016/j.eplepsyres.2017.07.006.

7. Dham BS, Hunter K, Rincon F. The epidemiology of status epilepticus in the United States. Neurocrit Care. 2014;20:476-83. doi: 10.1007/s12028-013-9935-x.

8. Berg AT, Shinnar S, Testa FM, et al. Status epilepticus after the initial diagnosis of epilepsy in children. Neurology. 2004;63:1027-34. doi: 10.1212/01.WNL.0000138425.54223.DC.

9. Riviello JJ, Ashwal S, Hirtz D, et al. Practice parameter: Diagnostic assessment of the child with status epilepticus (an evidencebased review). Neurology. 2006;67:1542-50. doi: 10.1212/01.wnl.0000243197.05519.3d.

10. Marik PE, Varon J. The management of status epilepticus. Chest. 2004;126:582-91. doi: 10.1378/chest.126.2.582.

11. Abou Khaled KJ, Hirsch LJ. Updates in the management of seizures and status epilepticus in critically ill patients. Neurol Clin. 2008;26(2):385-408. doi: 10.1016/j.ncl.2008.03.017.

12. Kantanen A, Sairanen J, Kälviäinen R. Incidence of the different stages of status epilepticus in Eastern Finland: A populationbased study. Epilepsy Behav. 2019; 101(Pt B):106413. doi: 10.1016/j.yebeh.2019.07.014.

13. Ferlisi $\mathrm{M}$, Shorvon $\mathrm{S}$. The outcome of therapies in refractory and super-refractory convulsive status epilepticus and recommendations for therapy. Brain. 2012;135:2314-28. doi: 10.1093/brain/aws091.

14. Lewena $\mathrm{S}$, Young $\mathrm{S}$. When benzodiazepines fail: how effective is second line therapy for status epilepticus in children. Emerg Med Australas. 2006;18:45-50. doi: 10.1111/j.1742-6723.2006.00807.x.

15. Barzegar M, Mahdavi M, Galegolab Behbehani A, Tabrizi A. Refractory convulsive status epilepticus in children: etiology, associated risk factors and outcome. Iran J Child Neurol. 2015;9(4):24-31. Available from: https://www.ncbi.nlm.nih.gov/ pmc/articles/PMC4670974/

16. Kravljanac R, Djuric M, Jankovic B, Pekmezovic T. Etiology, clinical course and response to the treatment of status epilepticus in children: a 16-year single-center experience based on 602 episodes of status epilepticus. Eur J Paediatr Neurol. 2015;19:584-90. doi: 10.1016/j.ejpn.2015.05.007.

17. Rai S, Drislanane F. Treatment of refractory and super-refractory status epilepticus. Neurotherapeutics. 2018;15(3):697-712. doi: 10.1007/s13311-018-0640-5.

18. Nardone R, Brigo F, Trinka E. Acute symptomatic seizures caused by electrolyte disturbances. J Clin Neurol. 2016;12(1):21-33. doi: 10.3988/jcn.2016.12.1.21.

19. Arayakarnkul $P$, Chomtho K. Treatment options in pediatric superrefractory status epilepticus. Brain Dev. 2018;41(4):359-66. doi: 10.1016/j.braindev.2018.11.011.

20. Maytal J, Shinnar S, Moshe SL, Alvarez LA. Low morbidity and mortality of status epilepticus in children. Pediatrics. 1989;83(3):323-31. PMID: 2919138.

21. Trinka E, Hofler J, Leitinger M, Brigo F. Pharmacotherapy for status epilepticus. Drugs. 2015;75:1499-521. doi: 10.1007/s40265-015-0454-2.

22. Pujar SS, Martinos MM, Cortina-Borja M, et al. Long-term prognosis after childhood convulsive status epilepticus: a prospective cohort study. Lancet Child Adolesc Heal. 2018;2(2):103-11. doi: 10.1016/\$2352-4642(17)30174-8.

23. Nelson-Chaure M, Chin RF, Neville BG, Scott RC. Outcome of paediatric convulsive status epilepticus: a systematic review. 
Lancet Neurol. 2006;5(9):769-79. doi: 10.1016/S1474-4422(06)70546-4.

24. Glauser T, Shinnar S, Gloss D, et al. Evidence based guideline: treatment of convulsive status epilepticus in children and adults: report of the guideline committee of the american epilepsy society. Epilepsy Curr. 2016;16:48-61. doi: 10.5698/1535-7597-16.1.48.

25. Lacroix J, Deal C, Gauthier M, Rousseau E, Farrell CA. Admissions to a pediatric intensive care unit for status epilepticus: a 10-year experience. Crit Care Med. 1994;22:827-32. doi: 10.1097/00003246-199405000-00019.

26. Chin RF, Neville BG, Peckham C, et al. Incidence, cause, and short-term outcome of convulsive status epilepticus in childhood: prospective population-based study. Lancet. 2016;368(9531):222-29. doi: 10.1016/S0140-6736(06)69043-0.

27. Fountain NB. Status epilepticus: risk factors and complications. Epilepsia. 2000;41:23-30. doi: 10.1111/j.1528-1157.2000.tb01521.x.

28. Dragoumi P, Tzetzi O, Vargiami E, et al. Clinical course and seizure outcome of idiopathic childhood epilepsy: determinants of early and longterm prognosis. BMC Neurol. 2013;13:206 doi: 10.1186/1471-2377-13-206.

29. Chegondi M, Garland MM, Sendi P, Jayakar AR, Totapally B. Course and outcome of children with convulsive status epilepticus admitted to a pediatric intensive care unit. Cureus. 2019;11(4):e4471. doi: $10.7759 /$ cureus.4471.

30. Berg AT, Shinnar S. Complex febrile seizures. Epilepsia. 1996;37:126-33. doi: 10.1111/j.1528-1157.1996.tb00003.x.

31. Berg AT, Shinnar S, Hauser WA, et al. A prospective study of recurrent febrile seizures. N Engl J Med. 1992;327:1122-7. doi: 10.1056/NEJM199210153271603.

32. Maytal J, Shinnar S. Febrile status epilepticus. Pediatrics. 1990;86:611-6.

33. Nelson KB, Ellenberg JH. Prognosis in children with febrile seizures. Pediatrics. 1978;61(5):720-7. PMID: 662510.

34. Shinnar S, Hesdorffer DC, Nordli DR, et al. Phenomenology of prolonged febrile seizures: Results of the FEBSTAT study. Neurology. 2008;71(3):170-6. doi: 10.1212/01.wnl.0000310774.01185.97.

35. Shinnar S, Pellock JM, Berg AT, et al. Short-term outcomes of children with febrile status epilepticus. Epilepsia. 2001;42:47-53. doi: 10.1046/j.1528-1157.2001.10000.x.

36. Sofijanov N, Emoto S, Kuturec M, et al. Febrile seizures: Clinical characteristics and initial EEG. Epilepsia. 1992;33:52-7. doi: 10.1111/j.1528-1157.1992.tb02282.x.

37. OECD. Enrolment in childcare and pre-school. OECD Family Database; 2019. p. 1-8. Available from: http://www.oecd.org/ els/soc/PF3_2_Enrolment_childcare_preschool.pdf

38. Matz O, Zdeblik C, Zechbauer S, Bündgens L, Litmathe J, Willmes K. Lactate as a diagnostic marker in transient loss of consciousness. seizure. 2016:40:71-5. doi: 10.1016/j.seizure.2016.06.014.

39. Fullor BM, Dellinger RP. Lactate as a hemodynamic marker in the critically ill. Curr Opin Crit Care. 2012;18(3):267-72. doi: 10.1097/MCC.0b013e3283532b8a.

40. Shuai J, Bikson M, Hahn PJ, Lian J, Durand DM. Ionic mechanisms underlying spontaneous CA1 neuronal firing in $\mathrm{Ca} 2+$-free solution. Biophys J. 2003;84(3):2099-111. doi: 10.1016/S0006-3495(03)75017-6.

41. Yue WD, Zhang YH, Gu F, Wang J, Zhang JY, Gu R. Mechanisms underlying low [Ca2+]-induced increased excitability of hippocampal neurons. Neurosci Bull. 2008;24(6):367-73. doi: 10.1007/s12264-008-0429-3.

42. Farrar HC, Chande VT, Fitzpatrick DF, et al. Hyponatremia as the cause of seizures in infants: a retrospective analysis of incidence, severity, and clinical predictors. Ann Emerg Med. 1995;26:42-8. doi: 10.1016/S0196-0644(95)70236-9.

43. Sterns RH, Thomas DJ, Herndon RM. Brain dehydration and neurologic deterioration after rapid correction of hyponatremia. Kidney Int. 1989;35:69-75. doi: 10.1038/ki.1989.9.

44. Barolomei F, Gastaut JL. Complex partial status epilepticus provoked by hyponatremia. Eur Neurol. 1998;40(1):53-4. PMID: 9729113.

45. Hirtz D, Ashwal S, Berg A, et al. Practice parameter: evaluating a first nonfebrile seizure in children: report of the quality standards subcommittee of the American Academy of Neurology, The Child Neurology Society, and The American Epilepsy Society. Neurology. 2000;55:616-23. doi: 10.1212/WNL.55.5.616.

46. Castilla-Guerra L, del Carmen Fernández-Moreno M, LopezChozas JM, Fernández-Bolaños R. Electrolytes disturbances and seizures. Epilepsia. 2006;47(12):1990-8. doi: 10.1111/j.1528-1167.2006.00861.x.

47. Zifman E, Alehan F, Menascu S, et al. Clinical characterization of gastroenteritis-related seizures in children: impact of fever and serum sodium levels. J Child Neurol. 2011;26:1397-400. doi: $10.1177 / 0883073811409222$.

48. Holtkamp M, Othman J, Buchheim K, Meierkord H. Predictors and prognosis of refractory status epilepticus treated in a neurological intensive care unit. J Neurol Neurosurg Psychiatry. 2005; $75: 534-9$. doi: 10.1136/jnnp.2004.041947.

49. Bellante F, Legros B, Depont C, Creteur J, Taccone FS, Gaspard N. Midazolam and thiopental for the treatment of refractory status epilepticus: a retrospective comparison of efficacy and safety. J Neurol. 2016;263:799-806. doi: 10.1007/s00415-016-8074-7.

50. Topjian AA, Gutierrez-Colina AM, Sanchez SM, et al. Electrographic status epilepticus is associated with mortality and worse short-term outcome in critically ill children. Crit Care Med. 2013;41(1):215-23. doi: 10.1097/CCM.0b013e3182668035.

51. Payne ET, Zhao XY, Frndova $H$, et al. Seizure burden is independently associated with short term outcome in critically ill children. Brain. 2014;137:1429-38. doi: 10.1093/brain/awu042.

52. Gulla KM, Sachdev A. Illness severity and organ dysfunction scoring in pediatric intensive care unit. Indian J Crit Care Med. 2016;20:27-35. doi: 10.4103/0972-5229.173685.

53. Shorvon S. Super-refractory status epilepticus: An approach to therapy in this difficult clinical situation. Epilepsia. 2011;52:53-6. doi: 10.1111/j.1528-1167.2011.03238.x.

54. Sadik KC, Mishra D, Jureya M, Jhamb U. Clinico-etiological profile of pediatric refractory status epilepticus at a public hospital in India. J Epilepsy Res. 2019;9:36-41. doi: 10.14581/jer.19004.

55. Sahin S, Yazici MU, Ayar G, Karalok ZS, Arhan EP. Seizures in a pediatric intensive care unit: a prospective study. J Trop Pediatr. 2016;62(2):94-100. doi: 10.1093/tropej/fmv076.

56. Komur M, Arslankoylu AE, Okuyaz Ç, Keçeli M, Derici D. Management of patients with status epilepticus treated at a pediatric intensive care unit in Turkey. Pediatr Neurol. 2012;46:382-6 doi: 10.1016/j.pediatrneurol.2012.03.013.

57. Specchio N, Pietrafusa N, Bellusci $M$, et al. Pediatric status epilepticus: Identification of prognostic factors using the new ILAE classification after 5 years of follow-up. Epilepsia. 2019;60(12):2486-98. doi: 10.1111/epi.16385. 